\title{
Introduction
}

The Scientific Spring meeting of the two Dutch Microbiological Societies (NVMM \& NVvM) will be held 20-22 April, 2009 in Papendal, Arnhem, The Netherlands.

The central theme of the plenary Tuesday-morning session is "Microbes go Extreme". Within this theme several renowned speakers will highlight some very extreme conditions that microbes encounter and resist in their direct environment. This illustrates the enormous potential of microorganisms to spread to the most bizarre niches over the entire globe, some of which we would not directly relate to as hospitable to life.

After the plenary session the 'Kiemprijs "will be awarded to three young investigators. This year the Westerdijk award and the Van Leeuwenhoek award will be initiated, both from NVMM and NVvM.

After lunch, we continue in six parallel sessions for the remainder of the meeting. Microbiologists throughout The Netherlands will present their exciting data. As in other years the poster session will be held on Tuesday evening with free drinks and of course followed by the party. To enhance the standing of our meeting we have invited more national and international speakers then before. You will find these prominent speakers in various sessions throughout the meeting.

The two meetings days will be preceded by a teaching and exam day for "artsen-microbioloog in opleiding" on Monday. Also on Monday we will start with a Premeeting Workshop and we want to encourage all of you to consider organizing such a premeeting workshop next year in your field of expertise. The first premeeting workshop deals with LEAN.

We look forward to an exciting and inspiring meeting and share new data and insight in Microbiology in all its aspects.

The organizing committee

Program plenary session Tuesday morning

Microbes go Extreme

Microbes inside

W. M. de Vos, Wageningen \& Helsinki University, Wageningen/Helsinki, The Netherlands/Finland

Genetic diversity of nematodes in arctic and antarctic ecosystems

S. Mattiucci, Sapienza, University of Rome, Rome, Italy

Archaeal viruses from high temperature environments: Integrating evolution, ecology, and biochemistry

M. Young, Montana State University-Bozeman, Bozeman, USA

Fungal virulence, vertebrate endothermy, and dinosaur extinction: is there a connection?

A. Casadevall, Albert Einstein College of Medicine, Bronx, USA 


\section{Organizing committee}

Prof. dr. J. A. G. van Strijp, chairman

Dr. A. J. W. van Alphen

Dr. C. H. E. Boel

Prof. dr. S. Brul

Prof. dr. L. Dijkhuizen

Mw. Dr. B. Duim

Prof. dr. J. M. D. Galama

Mw. Dr. J. W. B. van der Giessen

Prof. dr. P. W. M. Hermans

Prof. dr. ir. M. S. M. Jetten

Mw. Prof. dr. M. P. G. Koopmans

Prof. dr. P. Rottier

Prof. dr. P. H. M. Savelkoul

Prof. dr. L. J. Stal

Dr. M. J. H. M. Wolfhagen

Prof. dr. H. A. B. Wösten

Prof. dr. ir. M. H. Zwietering

\section{Poster committee}

Mw. drs. L. M. Kortbeek, voorzitter

Dr. W. van Schaik

Mw. dr. A. M. Wensing

Prof. dr. ir. M. H. Zwietering

The Scientific spring meeting is organized by the Dutch Society of Medical Microbiology (NVMM) and the Dutch Society of Microbiology (NVvM).

\section{ZonMW
AL $\overparen{W}$}

Microbiology awards 2009

\section{Poster award (sponsored by Yakult)}

EUR 250 will be awarded for the best poster presentation.

\section{Kiem award (Kiemprijs)}

Three prizes, EUR 500 each, will be awarded to three $\mathrm{PhD}$-students for a first scientific paper.
Westerdijk award (sponsored by Antonie van Leeuwenhoek, International Journal of General and Molecular Microbiology)

The best thesis within the broad area of microbiology will be awarded with an amount of EUR 1.000.

Van Leeuwenhoek award

A prize of EUR 2.000 is awarded to the postdoctoral fellow with the best achievements in microbiology in the preceding years.

All prizes cover the areas of Microbiology in the broadest sense: parasitology, virology, bacteriology, mycology, molecular studies, epidemiological studies, clinical microbiology, microbe-host interaction, biotechnological aspects and further. Four committees will judge the proposals.

Award ceremony, Tuesday 21 April, 13:00-13:30 hours

Directly after the plenary session the winners of the Kiem award, Westerdijk award and Van Leeuwenhoek award will be announced. 